\title{
Hubungan Kontrol Diri Guru dengan Intensi Melakukan Kekerasan Terhadap Siswa
}

\author{
Djuwariyah
}

\begin{abstract}
Violence in school that is performed by teachers occurred because of one of these factors: lack of teaching skills, lack of morality, lack of responsibility and lack of self-control. Teachers with such minor characters are not able to teach properly and are not able to make a good emotional interactions with students. Among those factors, self-control takes into account in supporting teachers to avoid violence towards students. Therefore, the current study aims at researching correlation between teachers self-control with intention to do violence towards students. Using statistical analysis, this research found that there is significant correlation between teachers'self-control with intention to do violence towards students. It is shown through correlation co-efficient $r=-0.684$ with $p=0.000(p<0.01)$. This means the lower self-control which teachers have, the lower the intention to do violence towards students. This study may have significant contribution for enhancing teachers ability to control themselves in the class, and have significant salient data for the next research.
\end{abstract}

Keywords: teachers, self-control, intention to do violence, students, school violence.

* Penulis adalah dosen tetap Program Studi Pendidikan Agama Islam FIAI UII Yogyakarta.

\section{A. Pendahuluan}

Pendidikan pada dasarnya merupakan interaksi antara pendidik dengan peserta didik untuk mencapai tujuan pendidikan yang berlangsung dalam lingkungan tertentu. Peranan pendidik lebih besar karena kedudukannya sebagai orang yang lebih dewasa, lebih berpengalaman, lebih banyak menguasai nilai-nilai, pengetahuan dan keterampilan (Sukmadinata, 2004). Oleh karena itu, dalam lingkungan pendidikan, guru merupakan salah satu komponen penting dalam sekolah yang memiliki pengaruh cukup besar terhadap peserta didik.

Guru sebagai pribadi, pendidik, pengajar dan pembimbing, dituntut memiliki kematangan atau kedewasaan pribadi, serta kesehatan jasmani dan rohani. Minimal ada tiga ciri kedewasaan tersebut, yaitu: pertama, telah memiliki tujuan dan pedoman hidup (philosophy of life), yaitu sekumpulan nilai yang ia yakini kebenarannya dan menjadi pegangan dan pedoman hidupnya; kedua, mampu melihat segala sesuatu secara objektif. Tidak dipengaruhi oleh subjektivitas dirinya; ketiga, mampu bertanggung jawab. Guru harus terdiri atas orang-orang yang bisa bertanggung jawab atas segala perbuatannya. Perbuatan yang bertanggung jawab adalah perbuatan yang berencana, yang dikaji terlebih dahulu sebelum dilakukan (Sukmadinata, 2004).

Sejalan dengan penjelasan di atas, Sardiman (2007) menyatakan bahwa guru sebagai pendidik harus mampu menjadikan dirinya sebagai teladan. Guru tidak perlu menganggap dirinya sebagai manusia super, manusia yang serba tahu dan tak pernah melakukan kesalahan. Guru harus berlaku biasa, terbuka serta menghindarkan segala perbuatan tercela dan tingkah laku yang akan menjatuhkan martabat sebagai seorang pendidik

Hidayati (2009) menyatakan bahwa seorang guru yang perannya sebagai pribadi, pendidik, pengajar dan pembimbing, dalam arti seharusnya menjadi teladan dan pemberi bekal ilmu bagi masa depan anak-anak didiknya, saat ini justru menjadi sosok yang paling ditakuti oleh anak didiknya karena adanya berbagai kasus penganiayaan yang sering melibatkan guru dan murid di sekolah. 
Sebagai contoh di Pacitan, seorang siswa meninggal dunia karena dihukum oleh gurunya dengan cara lari mengelilingi lapangan sebanyak 20 kali. Siswa yang dihukum lari itu terjatuh karena dipukul dengan tongkat oleh gurunya gara-gara kelelahan dan tidak lagi kuat berlari, kepalanya membentur batu hingga kemudian tewas (http://www.lpmpjateng.go.id/web/ index.php?option=com).

Kasus di atas adalah contoh kecil dari kekerasan fisik yang terjadi dalam dunia pendidikan dan masih banyak kasus serupa terjadi, namun tidak terekspos oleh media massa. Seperti di Jawa Tengah, 80 persen guru mengaku telah menghukum anak dengan membentak di depan teman-teman sekelasnya, sedangkan 55 persen guru telah menyuruh anaknya berdiri di depan kelas. Sementara itu, di Sulawesi Selatan, 90 persen guru menghukum muridnya dengan berdiri di depan kelas, 73 persen membentak muridnya, dan 54 persen guru menyuruh siswa membersihkan toilet. Kasus di Sumatera Utara, 90 persen guru menyuruh murid berdiri di depan kelas, 80 persen membentak, dan 50 persen menyuruh menulis berulang-ulang (Novianti, 2008).

Sejalan dengan di atas, Berdasarkan wawancara peneliti dengan beberapa murid di salah satu sekolah menengah kejuruan swasta di Yogyakarta bahwa mereka biasanya mendapat hukuman berupa lari keliling lapangan ataupun dijemur di lapangan sekolah jika terlambat masuk sekolah atau ketika tidak mengerjakan PR. Sedangkan yang lain mengaku sering melihat temannya diberi hukuman oleh guru berupa membersihkan kamar mandi sekolah, dibentak di hadapan siswa lainnya bahkan dipukuli dengan rotan ketika melakukan kesalahan.

Menurut Huraerah (2007) kekerasan di sekolah bisa terjadi karena beberapa faktor, antara lain yaitu: kebanyakan guru kurang menghayati pekerjaannya sebagai panggilan profesi sehingga cenderung kurang memiliki kemampuan mendidik dengan benar serta tidak mampu menjalin ikatan emosional yang konstruktif dengan siswa; dengan dalih demi kedisiplinan siswa, guru seringkali kehilangan kesabaran hingga melakukan hukuman fisik atau melakukan tindakan-tindakan yang tidak terpuji dan melanggar batas etika dan moralitas; kurikulum terlalu padat dan kurang berpihak kepada siswa sehingga mengakibatkan guru cenderung menjalankan tugasnya sekedar mengejar target kurikulum.
Selain itu, penyebab terjadinya tindak kekerasan oleh guru terhadap siswa dapat dilihat dari faktor individual dan faktor sistem. Faktor individual bersumber dari individu guru yang kurang mampu menguasai emosi, kurang pengetahuan terhadap hal-hal yang berkaitan dengan peraturan mengenai tindak kekerasan (undang-undang perlindungan anak), persepsi terhadap pemberian hukuman dan interpretasi terhadap hukuman fisik. Sementara dari faktor sistem bersumber pada sistem pengawasan atau kontrol terhadap perilaku anak merupakan aturan yang telah ditetapkan secara tertulis sementara yang mengatur perilaku guru dalam melaksanakan proses belajar mengajar belum diatur dengan aturan tertulis (Pramono dkk, 2009).

Berdasarkan penjelasan-penjelasan di atas, faktor-faktor penyebab guru melakukan tindak kekerasan dapat berasal dari faktor internal maupun eksternal guru. Kedua faktor tersebut dapat menjadi pemicu terjadinya tindak kekerasan apabila guru tidak memiliki kontrol diri yang baik.

Guru adalah tenaga pendidik yang memberikan sejumlah pengetahuan kepada anak didik di sekolah serta bertugas menanamkan nilai-nilai dan sikap kepada anak didik agar memiliki kepribadian yang baik (Fatthurrohman \& Sutikno, 2007). Oleh karena itu, seorang guru harus memiliki kontrol diri yang baik karena apa yang diucapkan dan dilakukan akan menjadi rujukan bagi anak didik bahkan masyarakat di sekitarnya. Jika seorang guru dalam kesehariannya senantiasa berkata dengan perkataan yang kasar, berperilaku yang menyimpang dari etika dan moral, maka ia akan memberikan dampak buruk bagi anak didik dan tentu akan mencoreng citra profesionalitas guru.

Setiap individu memiliki suatu mekanisme yang dapat membantu mengatur dan mengarahkan perilaku, yaitu kontrol diri. Menurut Chaplin (2001) kontrol diri adalah kemampuan untuk membimbing tingkah laku sendiri, kemampuan untuk menekan atau merintangi tingkah laku impulsif. Sementara itu, Suyasa (2004) mengatakan kontrol diri adalah kemampuan individu untuk menahan keinginan yang bertentangan dengan tingkah laku yang tidak sesuai dengan norma sosial yang dapat diidentikkan sebagai kemampuan individu untuk bertingkah laku sesuai dengan norma sosial yang berlaku. Sebagai salah satu sifat kepribadian, kontrol diri pada satu individu dengan individu yang lain tidaklah sama. Ada individu yang memiliki kontrol diri yang tinggi 
dan ada individu yang memiliki kontrol diri yang rendah.

Guru yang memiliki kontrol diri yang tinggi akan mampu mengarahkan dan mengatur perilakunya secara positif serta mempertimbangkan konsekuensi yang mungkin dihadapi sehingga menghindari untuk melakukan tindakan kekerasan pada siswanya. Sebaliknya, guru yang memiliki kontrol diri yang rendah kurang mampu mengarahkan dan mengatur perilakunya secara positif dan mempertimbangkan konsekuensi yang mungkin dihadapi sehingga tidak dapat menghindari untuk melakukan tindakan kekerasan pada siswanya. Seorang guru yang memiliki peran sebagai pendidik, pengajar dan pembimbing, diharapkan memiliki kontrol diri yang tinggisehingga mampumenginterpretasikan stimulus yang dihadapi, mempertimbangkan konsekuensinya sehingga mampu memilih tindakan yang tepat. Oleh karena itu, pertanyaan penelitian yang diajukan adalah apakah ada hubungan antara kontrol diri guru dengan intensi melakukan kekerasan terhadap siswa.

\section{B. Kerangka Teori}

\section{Intensi Melakukan Kekerasan}

Menurut Fishbein dan Ajzen (1975) intensi adalah komponen dalam diri individu yang mengacu pada keinginan untuk melakukan tingkah laku tertentu. Sukirno dan Hadi (2007) menyatakan intensi merupakan kesungguhan niat individu untuk melakukan perilaku tertentu dalam rangka memenuhi motif berperilakunya.

Menurut Geen (Krahe, 2005) kekerasan didefinisikan sebagai pemberian tekanan intensif terhadap orang atau properti dengan tujuan merusak, menghukum atau mengontrol. Sementara Douglas dan Waksler (Assegaf, 2004) berpendapat bahwa istilah kekerasan (violence) digunakan untuk menggambarkan perilaku yang disertai penggunaan kekuatan pada orang lain, secara terbuka (overt) maupun tertutup (covert), baik yang menyerang (offensive) maupun bertahan (defensive).

Hayati(2002)menyatakanbahwakekerasanpada dasarnya adalah semua bentuk perilaku, baik verbal maupun nonverbal yang dilakukan oleh seseorang atau sekelompok orang terhadap seseorang atau sekelompok orang lainnya sehingga menyebabkan efek negatif secara fisik, emosional dan psikologis terhadap orang yang menjadi sasarannya. Kekerasan pada siswa menurut Susilowati (2010) adalah suatu tindakan keras yang dilakukan terhadap siswa di sekolah dengan dalih mendisiplinkan siswa.

Berdasarkan beberapa pengertian di atas, peneliti menyimpulkan bahwa intensi melakukan kekerasan terhadap siswa adalah dorongan yang dimiliki oleh individu (dalam hal ini adalah guru) untuk melakukan suatu tindakan yang dapat menyakiti ataupun menimbulkan efek negatif terhadap siswa dengan maksud untuk mendisiplinkan siswa.

Menurut Assegaf (2004) bentuk-bentuk tindak kekerasan yaitu:

1. Kekerasan terbuka: kekerasan yang dilakukan seseorang terhadap orang lain yang dapat dilihat dan diamati secara langsung. Bentuk tindak kekerasan ini berkaitan dengan tindakan kekerasan fisik.

2. Kekerasan tertutup: kekerasan yang dilakukan seseorang terhadap orang lain secara tersembunyi. Bentuk tindak kekerasan ini berkaitan dengan tindak kekerasan secara psikis.

3. Kekerasan agresif: kekerasan yang dilakukan seseorang terhadap orang lain dengan tujuan mendapatkan sesuatu. Bentuk tindak kekerasan ini berkaitan dengan perilaku kekerasan secara seksual.

4. Kekerasan defensif: kekerasan yang dilakukan sebagai tindakan perlindungan. Tindak kekerasan guru terhadap siswa dalam hal ini memiliki tujuan untuk melindungi namun tindakan tersebut baik secara langsung maupun tidak langsung dapat menyakiti ataupun membebani siswa.

\section{Kontrol Diri}

Menurut Suyasa (2004) kontrol diri adalah kemampuan individu untuk menahan keinginan yang bertentangan dengan tingkah laku yang tidak sesuai dengan norma sosial yang dapat diidentikkan sebagai kemampuan individu untuk bertingkah laku sesuai dengan norma sosial yang berlaku. Sementara itu, menurut Chaplin (2001) kontrol diri adalah kemampuan untuk membimbing tingkah laku sendiri, kemampuan untuk menekan atau merintangi tingkah laku impulsif.

Menurut Averil, dkk (Sarafino, 1994) terdapat lima aspek kontrol diri yang digunakan 
dalam kehidupan sehari-hari, yaitu:

1. Kontrol perilaku (behavioral control); meliputi kemampuan dalam mengambil tindakan nyata untuk mengurangi dampak dari stressor. Kemungkinan tindakan ini dapat mengurangi tingkat ketegangan suatu atau mempersingkat durasi masalah.

2. Kontrol kognitif (cognitive control): didefinisikan sebagai kemampuan seseorang dalam menggunakan proses berpikir atau strategi ketika menghadapi permasalahan. Hal ini dapat dilakukan dengan cara memfokuskan pikiran terhadap hal-hal yang menyenangkan, netral atau suatu sensasi yang berbeda dengan situasi yang dihadapinya.

3. Kontrol dalam pengambilan keputusan (decisional control); didefinisikan sebagai suatu kesempatan untuk memilih antara pilihan alternatif atau tindakan umum. Menurut Averil (Zulkarnain, 2002) kontrol dalam pengambilan keputusan merupakan kemampuan seseorang untuk memilih hasil atau suatu tindakan berdasarkan pada sesuatu yang diyakini atau disetujui oleh dirinya.

4. Kontrol informasi (informational control); kontrol terhadap informasi meliputi hal-hal yang berkaitan dengan pengetahuan tentang masalah yang dihadapinya, seperti apa yang akan terjadi, mengapa, dan konsekuensi apa yang akan diterimanya.

5. Kontrol pengalaman masa lalu (retrospective control); didefinisikan sebagai keyakinan terhadap apa atau siapa yang menyebabkan suatu permasalahan tersebut. Seseorang seringkali mencoba untuk mencari arti dari berbagai kejadian dalam hidup mereka. Meskipun demikian, hal tersebut tidak membantu seseorang dalam mengontrol apa yang akan terjadi tetapi dapat membantu seseorang untuk menerima dan mengatasi permasalahannya.

\section{Hipotesis}

Hipotesis dalam penelitian ini adalah ada hubungan negatif antara kontrol diri guru dengan intensi melakukan kekerasan terhadap siswa di sekolah. Artinya semakin tinggi kontrol diri guru maka semakin rendah intensi melakukan kekerasan terhadap siswa di sekolah dan sebaliknya.

\section{Metode Penelitian \\ 1. Subjek Penelitian}

Subjek dalam penelitian ini adalah para guru SMK Muhammadiyah Pakem, berjenis kelamin pria maupun wanita dan memiliki status sebagai guru tetap maupun guru honorer (tidak tetap).

\section{Metode Pengumpulan Data}

Metode pengumpulan data dalam penelitian ini dilakukan dengan menggunakan skala yaitu skala intensi melakukan kekerasan dan skala kontrol diri guru.

\section{Alat Ukur}

\section{a) Skala Intensi Melakukan Kekerasan}

Skala intensi melakukan kekerasan dibuat berdasarkan bentuk-bentuk tindak kekerasan menurut Assegaf (2004). Hasil analisis uji coba skala intensi melakukan kekerasan menunjukkan dari 60 aitem yang diujicobakan menghasilkan 31 item yang sahih. Koefisien corrected item-total correlation berkisar antara 0.272 sampai dengan 0.658 dengan koefisien reliabilitas alpha $(\alpha)$ sebesar 0.913 .

\section{b) Skala Kontrol Diri Guru}

Skala kontrol diri guru dibuat berdasarkan aspek-aspek kontrol diri menurut Averill, dkk (Sarafino, 1994). Hasil analisis uji coba skala kontrol diri guru menunjukkan dari 60 aitem yang diujicobakan menghasilkan 30 item yang sahih. Koefisien corrected item-total correlation berkisar antara 0.287 sampai dengan 0.761 dengan koefisien reliabilitas alpha $(\alpha)$ sebesar 0.928 .

\section{Metode Analisis Data}

Data yang diperoleh selanjutnya dianalisis secara statistik dengan menggunakan program olah data SPSS 17 for windows. Teknik korelasi yang digunakan adalah teknik korelasi product-moment dari Pearson. 


\section{Hasil Penelitian}

\section{Deskripsi Subjek Penelitian}

Tabel 1: Deskripsi Subjek Penelitian Berdasarkan Jenis Kelamin

\begin{tabular}{|l|l|l|}
\hline \multicolumn{1}{|c|}{ Jenis Kelamin } & Jumlah & Persentase \\
\hline Pria & 36 & $73.5 \%$ \\
\hline Perempuan & 13 & $26.5 \%$ \\
\hline \multicolumn{1}{|c|}{ Total } & $\mathbf{4 9}$ & $\mathbf{1 0 0 \%}$ \\
\hline
\end{tabular}

Tabel 2: Deskripsi Data Penelitian

\begin{tabular}{|l|l|l|l|c|l|l|l|c|}
\hline \multirow{2}{*}{ Variabel } & \multicolumn{4}{|c|}{ Hipotetik } & \multicolumn{4}{c|}{ Empirik } \\
\cline { 2 - 9 } & Min & Max & Mean & SD & Min & Max & Mean & SD \\
\hline IMK & 31 & 124 & 77.5 & 15.5 & 34 & 77 & 58 & 8.5 \\
\hline KD & 30 & 120 & 75 & 15 & 75 & 113 & 95 & 7.2 \\
\hline
\end{tabular}

Keterangan :

IMK = intensi melakukan kekerasan

$\mathrm{KD}=$ kontrol diri

Subjek dalam penelitian ini digolongkan ke dalam tiga kategorisasi yaitu rendah, sedang dan tinggi. Hasil kategorisasi intensi melakukan kekerasan diuraikan pada tabel 3 berikut ini.

Tabel 3: Kategorisasi Data Intensi Melakukan Kekerasan

\begin{tabular}{|c|l|l|l|}
\hline Kategori & Rentang Skor & Jumlah & Persentase \\
\hline Tinggi & $\mathrm{X}>93$ & 0 & $0 \%$ \\
\hline Sedang & $93>\mathrm{X} \geq 62$ & 15 & $30.6 \%$ \\
\hline Rendah & $\mathrm{X}<62$ & 34 & $69.4 \%$ \\
\hline Jumlah & & $\mathbf{4 9}$ & $\mathbf{1 0 0 \%}$ \\
\hline
\end{tabular}

Hasil kategorisasi kontrol diri guru diuraikan pada tabel 4 berikut ini.

Tabel 4: Kategorisasi Data Kontrol Diri Guru

\begin{tabular}{|l|l|l|l|}
\hline Kategori & Rentang Skor & Jumlah & Persentase \\
\hline Tinggi & $\mathrm{X}>90$ & 38 & $77.6 \%$ \\
\hline Sedang & $90>\mathrm{X} \geq 60$ & 11 & $22.4 \%$ \\
\hline Rendah & $\mathrm{X}<60$ & 0 & $0 \%$ \\
\hline Jumlah & & $\mathbf{4 9}$ & $\mathbf{1 0 0 \%}$ \\
\hline
\end{tabular}

\section{Hasil Uji Asumsi}

\section{a) Uji Normalitas}

Hasil uji normalitas untuk skala intensi melakukan kekerasan memenuhi distribusi normal dengan koefisien Kolmogorof-Smirnov Z (K-SZ) sebesar 0.818 dengan $p=0.515(p>0.05)$. Untuk skala kontrol diri juga dapat memenuhi distribusi normal dengan koefisien Kolmogorof-Smirnov Z $(\mathrm{K}-\mathrm{SZ})$ sebesar 0.844 dengan $\mathrm{p}=0.474(\mathrm{p}>0.05)$.

\section{b) Uji Linearitas}

Hasil uji linearitas hubungan antara variabel kontrol diri dengan variabel intensi melakukan kekerasan menunjukkan $\mathrm{F}=39.178$ dan $\mathrm{p}=0.000(\mathrm{p}<0.05)$ yang berarti ada hubungan linear antara variabel kontrol diri dengan variabel intensi melakukan kekerasan.

\section{Hasil Uji Hipotesis}

Uji hipotesis dalam penelitian ini menggunakan teknik korelasi product-moment Pearson. Adapun hipotesis yang diajukan dalam penelitian ini adalah ada hubungan negatif antara kontrol diri guru dengan intensi melakukan kekerasan terhadap siswa. Hasil analisis data menunjukkan korelasi $(r)=-0.684$ dengan $p=0.000(p<0.01)$. Hasil analisis tersebut menunjukkan adanya hubungan yang sangat signifikan antara kedua variabel dan hipotesis yang diajukan diterima.

\section{E. Pembahasan}

Hasil penelitian menunjukkan bahwa hipotesis yang diajukan dalam penelitian ini diterima, yakni ada hubungan negatif yang sangat signifikan antara kontrol diri guru dengan intensi melakukan kekerasan terhadap siswa. Hal tersebut ditunjukkan oleh koefisien korelasi $r=-0.684$ dengan $p=0.000$ $(p<0.01)$. Artinya semakin tinggi kontrol diri yang dimiliki guru maka semakin rendah intensi melakukan kekerasan terhadap siswa. Sebaliknya, semakin rendah kontrol diri yang dimiliki guru maka semakin tinggi intensi melakukan kekerasan terhadap siswa.

Hasil penelitian ini sesuai dengan yang 
dikemukakan oleh Gottfredson dan Hirschi (Fox dkk, 2009) bahwa ketika diberikan kesempatan maka individu dengan kontrol diri rendah menjadi lebih mungkin untuk melakukan tindakan kriminal dibandingkan individu dengan kontrol diri yang tinggi. Ciri sifat yang menandakan kontrol diri rendah meliputi temperamental, mencari risiko, impulsif, berpusat pada diri sendiri dan lebih menyukai melakukan tindakan yang bersifat fisik.

Hasil kategorisasi intensi melakukan kekerasan dalam penelitian ini menunjukkan bahwa sebanyak 34 subjek (69.4\%) masuk dalam kategori intensi melakukan kekerasan rendah dan 15 subjek (30.6\%) masuk dalam kategori sedang. Sedangkan subjek yang termasuk dalam kategori tinggi tidak ada. Adanya intensi melakukan kekerasan terhadap siswa di sekolah dapat disebabkan oleh beberapa faktor. Menurut Huraerah (2007) salah satu faktor yang menyebabkan terjadinya kekerasan di sekolah adalah demi dalih mendisiplinkan siswa. Salah satu metode penggunaan sistem skor sebagai perhitungan pelanggaran tata tertib di sekolah ini memungkinkan untuk mempengaruhi dalam menghindari pemberian hukuman, khususnya hukuman secara fisik oleh guru terhadap murid sehingga tidak ada guru yang termasuk dalam kategori intensi melakukan kekerasan yang tinggi.

Penelitian Setiadi (2001) menyatakan bahwa perilaku kekerasan dapat dilakukan ketika setiap orang cenderung untuk mengingat efek positif dan melupakan efek negatif dari perbuatannya ataupun ketika pihak yang melakukan tindak kekerasan merasa memiliki kekuasaan. Munculnya bentuk perilaku kekerasan ini dapat terjadi ketika kesadaran diri (kontrol diri), kemampuan menilai diri dan kepedulian terhadap orang lain menurun. Hal tersebut sesuai yang dikemukakan Geyer dan Baumeister (dalam Vitell dkk, 2008) bahwa kontrol diri adalah kapasitas untuk bertindak menggunakan moral dengan menolak suatu kecenderungan untuk bertindak atau berperilaku buruk.

Fungsi kontrol diri menurut Vitell, dkk (2008) adalah kemampuan menahan diri dari perbuatan yang tidak diinginkan dan kecenderungan berperilaku yang secara moral diragukan. Sehingga dapat diartikan jika kontrol diri individu tinggi maka individu tersebut dapat menghindari keinginannya untuk melakukan suatu perilaku kekerasan.

Hasilkategorisasikontroldirigurumenunjukkan sebanyak 38 subjek (77.6\%) masuk dalam kategori kontrol diri tinggi dan 11 subjek (22.4\%) masuk dalam kategori sedang dan yang termasuk dalam kategori kontrol diri rendah tidak ada. Hal ini berarti bahwa sebagian besar subyek dapat mengontrol emosi dengan baik ketika ada siswa yang berperilaku memancing emosi atau dapat menghindari diri untuk tidak melakukan perilaku kekerasan terhadap siswa di sekolah sebagai dalih untuk mendisiplinkan siswa yang melanggar peraturan sekolah.

Kontrol diri yang dimiliki guru mempunyai hubungan yang cukup signifikan dengan intensi melakukan kekerasan terhadap siswa di sekolah. Hal tersebut ditunjukkan dengan sumbangan efektif untuk korelasi antara kontrol diri guru dengan intensi melakukan kekerasan terhadap siswa sebesar $46 \%$ sedangkan sisanya sebesar $54 \%$ berasal dari faktor lain yang tidak terlibat dalam penelitian yang mungkin dapat berperan mempengaruhi intensi guru melakukan kekerasan terhadap siswa. Faktor lain tersebut dapat berupa latar belakang sosial-ekonomi pelaku, lingkungan masyarakat dan tayangan media massa maupun buruknya sistem dan kebijakan pendidikan yang berlaku (Assegaf, 2004).

Adapun kelemahan dari penelitian ini adalah alat ukur yang digunakan masih harus disempurnakan lagi karena mengingat banyaknya item yang gugur. Hal tersebut diperlukan untuk mengungkap lebih banyak mengenai intensi yang dimiliki guru dalam melakukan kekerasan terhadap siswa maupun kontrol diri yang dimiliki guru.

\section{F. Kesimpulan dan Saran}

Berdasarkan hasil penelitian dan pembahasan yang telah diuraikan maka dapat disimpulkan bahwa ada hubungan negatif yang sangat signifikan antara kontrol diri guru dengan intensi melakukan kekerasan terhadap siswa.

Berdasarkan hasil penelitian yang telah dilakukan maka saran-saran yang dapat diberikan antara lain:

\section{Subjek Penelitian (Guru)}

Bagi para guru disarankan untuk sebisa mungkin selalu dapat mengendalikan diri atau mengontrol diri ketika menghadapi kenakalan siswa di sekolah ataupun perilaku siswa lainnya yang dapat menjadi stimulus bagi guru untuk melakukan tindak kekerasan. Sebaiknya para guru juga tidak 
menggunakan cara-cara yang mengarah pada kekerasan terhadap siswa dalam mendidik.

\section{Sekolah}

Bagi sekolah, disarankan untuk membuat suatu aturan tertulis yang disepakati bersama mengenai sanksi bagi setiap siswa yang melanggar aturan sekolah. Aturan tersebut juga hendaknya dibuat dengan memperhatikan hak maupun kewajiban semua unsur dalam sekolah. Selain itu, perlu diberikan sesekali suatu pelatihan yang dapat membantu guru dalam mengelola emosi-emosi positif yang dimiliki.

\section{Peneliti Selanjutnya}

Bagi peneliti selanjutnya yang ingin mengadakan penelitian yang sejenis disarankan untuk memperhatikan faktor lain yang mungkin berpengaruh terhadap intensi melakukan kekerasan pada guru. Selain itu populasi penelitian ini terbatas pada lingkup satu sekolah saja, oleh karena itu penelitian lanjutan dapat dilaksanakan pada populasi lebih besar. Penelitian pada populasi yang lebih besar diharapkan dapat memberikan gambaran lebih lengkap tentang hubungan kontrol diri guru dengan intensi melakukan kekerasan terhadap siswa di sekolah.

\section{Daftar Pustaka}

Assegaf, A. R. 2004. Pendidikan Tanpa Kekerasan. Cetakan Pertama. Yogyakarta: Tiara Wacana Yogya

Chaplin, J. P. 2001. Kamus Lengkap Psikologi (Edisi terjemahan). Jakarta: Raja Grafindo Persada

Faturrohman, P. \& Sutikno, S. 2007. Strategi Belajar Mengajar. Cetakan Pertama. Bandung: Refika Aditama

Fishbein, M \& Ajzen, I. 1975. Belief, Attitude, Intention and Behavior: Introduction to Theory and Research. Philippines: Publishing Company, Inc.

Fox, K.A., Gover, A.R., \& Kaukinen, C. 2009. The Effects of Low Self Control and Childhood Maltreatment on Stalking Victimization among Men and Women. Am J Crim Just. Vol. 34, 181197.

Hayati, E. N. 2002. Panduan Untuk Pendamping
Perempuan Korban Kekerasan. Yogyakarta: Rifka Annisa Women's Crisis Center

Hidayati, T.M. 2009. Manajemen Emosi Pada Siswa Korban Kekerasan Fisik Oleh Guru di Sekolah. Skripsi. Surakarta: Fakultas Psikologi Universitas Muhammadiyah Surakarta.

Huraerah, A. 2007. Child Abuse (Kekerasan Terhadap Anak). Edisi Revisi. Bandung: Penerbit Nuansa

Krahe, B. 2005. Perilaku Agresif (Buku Panduan Psikologi Sosial). Yogyakarta: Pustaka Pelajar

Novianti, I. 2008. Fenomena Kekerasan di Lingkungan Pendidikan. Jurnal Pemikiran Alternatif Pendidikan, Vol. 13 No. 2, 324-338.

Sarafino, E. P. 1994. Health Psychology: Bio Psychosocial Interactions (2nd ed.). New York: John Wiley \& Sons

Sardiman, A.M. 2007. Interaksi dan Motivasi Belajar Mengajar. Jakarta: Raja Grafindo Persada

Setiadi, B.N. 2001. Terjadinya Tindak Kekerasan Dalam Masyarakat. Jurnal Psikologi Sosial, No. IX, 59-68.

Sukirno, H. R. S. \& Hadi, S. 2007. Faktor-Faktor yang Mempengaruhi Intensi Membeli Produk Wayang Kulit Pada Masyarakat Suku Jawa. Jurnal Psikologika, No. 24, 123.

Sukmadinata, N.S. 2004. Landasan Psikologi Proses Pendidikan. Bandung: Remaja Rosdakarya

Suyasa, P. T. Y. S. 2004. Dari Anak Sampai Usia Lanjut: Bunga Rampai Psikologi Perkembangan. Jakarta: Gunung Mulia

Vitell, S.J., Bing, M.N., Davison, H.K., Ammeter, A.P., Garner, B.L., \& Novicevic, M.M. 2008. Religiosity and Moral Identity: The Mediating Role of Self-Control. Journal of Business Ethics, No. 88, 601-613.

Pramono, W., Dahlan, S., \& Indraddin, S.S. 2009. Pengkajian Kesejahteraan dan Perlindungan Anak (Studi Tentang Kekerasan Terhadap Anak di Lingkungan Pondok Pesantren Modern Provinsi Sumatera Barat). http://www. papantulisku.com/2010/12/faktor-pendorongdan-upaya-mencegah-dan.html. /17/1/2011 
http://www.lpmpjateng.go.id/web/index. php?option $=$ com_content $\&$ view $=$ article $\&$ id $=2$ 37:kekerasan-di-sekolah\&catid=93:ruangguru \&Itemid $=118 / 17 / 1 / 2011$ 